\title{
The Influence of Personal Growth Initiative and Self-Regulated Learning on Victims of Bullying and the Differences in Terms of Parental Educational Background
}

\author{
Putri Saraswati ${ }^{1, *}$ \\ ${ }^{1}$ Faculty of Psychology, Universitas Muhammadiyah Malang, Malang, Indonesia \\ *Correspondinge-mail: psaraswati@umm.ac.id
}

\begin{abstract}
Bullying victims have greater desire to develop themselves into a better person than the bully. In psychological terms, efforts to become a better person are called Personal Growth Initiatives (PGI). Individuals with good PGI will continue to strive to develop themselves. In this context, the PGI is in an academic setting. This PGI affects students' Self-Regulated Learning (SRL). This SRL enables students to maintain their learning performance in order to get the desired learning outcomes. In the case of students who are victims of bullying, they have psychological characteristics that cause them not to be optimal in learning and fail in learning activities. This study aims to determine the effect of PGI on students' SRL who become victims of bullying. In addition, this study also aims to reveal whether the PGI and SRL of bullying victims are affected by parents' educational background. The subjects of this study are 42 students of become victims of bullying in Junior High School. The sampling technique used is purposive sampling. Data are collected using a Likert scale for PGI and SRL variables. The data are analyzed by using linear regression to determine the effect of PGI and SRL and ANOVA to determine the role of parents' educational background in the students' PGI and SRL. The results of statistical calculations show that PGI affect SRL $(\mathrm{F}=36.120, \mathrm{p}<0.001)$ and $\mathrm{Y}=0.814+0.711 \mathrm{X}$. The higher the PGI the greater the bullying victims' SRL. Other results show parents' educational background does not contribute to the students' PGI and SRL. This means that different educational levels of the parents do not affect the PGI and SRL levels of their children, who become victims of bullying. The mean of bullying victims' PGI about $3.2-3.4$ and mean of SRL $3.0-3.2$.
\end{abstract}

Keywords: "Personal Growth Initiative”, "Self-Regulated Learning”, “Bullying victims”.

\section{INTRODUCTION}

Bullying occurs in many countries. In 2019, UNESCO held a general conference to fight bullying in schools. This conference was held because $32 \%$ of students in the world were victims of bullying. According to data from KPAI (Indonesian Children Protection Commission), there were 2,473 cases of bullying to children in Indonesia that occurred in educational institutions and social media during the last 9 years and continued to increase. Bullying at school is physical, verbal or psychological violence carried out with the aim of hurting someone [1][2]. Bullying is different from aggressive behavior, the difference lies in the unbalanced power between the perpetrator and the victim [1], where the perpetrator is more dominant and commits bullying repeatedly on purpose[3]. Prevalence of victims at the secondary school level is higher than the perpetrators of bullying[4]. In Indonesia, bullying cases are more prevalent at the junior high school level. This can be seen the news that published online [5] [6] [7].

Bullying affects its victims psychologically and physically. Victims of bullying usually suffer from low self-esteem, anxiety, depression and loneliness [8]. In addition, they also feel a life full of pressure [9] and dislike their peers [8]. The other impacts are physical and psychosomatic health problems [1]. These happen in academic environment. Feelings of pressure, anxiety, and health problems such as headache and other physical complaints affect their courage to go to school and even lead them to avoid school [1] or make them unable to concentrate at school. It makes bullying victims have less learning opportunities. 
Bullying at school affects the academic achievement of both victims and perpetrators [10] [11][3]. For the victims, in particular, bullying causes low academic achievement, lack of learning enthusiasm in completing school assignments [12][3]. Therefore, the objective of this study is to determine the effect of Personal Growth Initiation (PGI) on Self-Regulated Learning (SRL) of bullying victims.

elings in achieving learning goals, with which he will be active and systematically trying to achieve those goals[13]. According to Zimmerman and Schunk, SRL consists of three stages, planning, performance and self-reflection on the performance, which is continuous and active in nature [14]. Pintrich stated that SRL is active and constructive process in making goals for learning followed by monitoring, regulating and controlling cognitive, motivation and behavior so as to guide and direct the learning goals to be achieved [14]. The SRL process is not only done once but continuously in cyclical stages.

According to Pintrich and Zusho, factors that influence SRL include biological development, knowledge, strategies and expertise developed by an individual and his goals [15]. Zimmerman states that in social cognitive model SRL is influenced by social, environmental and individual roles [14]. Social factors can be in the form of family, teachers, friends, and others. Environmental factors can be in the form of prizes, awards, the physical environment, and etc. Individual or personal factors are all things that are inherent in the individual. When an individual has an intense desire and effort to become a better person or PGI, this is called a personal factor.

Based on the SRL framework, which states that SRL is an active process and one of the factors affecting SRL is an individual's personal condition, it can be said that PGI can direct one's SRL; wherein PGI is an individual effort to become a good person actively and continuously [16] [17] [18]. PGI is an intensive individual attachment between awareness and self-control to grow better in all aspects of life, including learning. People with good PGI have the readiness to change into better personalities, both in attitude and behavior. Becoming a better person is what encourages someone to continue to be active and to keep trying, including in learning activities, so that PGI can be linked to SRL. In Saraswati \& Amalia's research it is revealed that bullying victims have better PGI than bullying perpetrators[3]. This means that even though the victims feel depressed, stressed, fearful and encounter physical and
Bullying victims' poor psychological conditions affect their academic performance and achievement, so it is necessary to have good Self-Regulated Learning (SRL). SRL is influenced by Personal Growth Initiative (PGI), which can be explained in the framework of SRL. SRL is an individual's ability to manage thoughts, behavior, and fe

academic problems, they still have the desire and effort to become a better person.

Good SRL results in good academic achievement [19] [20] and academic performance [21]. Therefore, it is important for every student to have a good SRL in order to be able to learn independently and face challenges and difficulties while studying. A student with good SRL will not give up easily with the difficulties he feels. On the other hand, a student who is lacking of SRL will easily give up and be less satisfied with his learning outcomes. In addition, he will also feel pressured by the tasks he has to accomplish. The impact of the lack of SRL can also be felt emotionally. This is in line with the research of [22] which states that poor psychological wellbeing and academic life are caused by lack of selfregulation. Inadequate self-regulation results in failure to regulate thoughts, feelings and behaviors as well as the time and resources available [23].

As explained in the social cognitive theory, individual behavior, both SRL and PGI, is influenced by environmental factors, such as parents' educational background. According to [24] [25] parents' educational background is related to how their children will deal with bullying. In this case, the educated parents will be able to teach their children not to be victims of bullying. Therefore, parents' education is an important factor to reducing the effects of bullying in schools [26].

\section{METHOD}

This is a quantitative research. The subjects of this study were victims of bullying, male and female, in junior high schools in Malang. The sampling technique used was purposive sampling. The procedure used in selecting the subject was conducting observations and interviews with both teachers and students. The research subjects were 42 people who suffer from bullying.

The data in this study were taken using a Likert scale for PGI and SRL variables. PGI scale has a reliability of 0.806 [27] while SRL scale has a reliability of 0.929 [28]. Items on the PGI scale measure cognitive and behavioral dimensions, while 
items on the SRL scale measure cognitive processing (planning), performance, and self reflection. Examples of items on the SRL scale are "in learning, the most important thing is the result" and "I am disappointed with my learning outcomes", and examples of items on the PGI scale are "I am sure I can submit assignments on time" and "I try to contact the teacher/lecturer if there is something that makes me confused". The data obtained from the results of this study were analyzed using simple linear regression statistical techniques and anova test.

\section{RESULT}

Demographic data of research subjects are all students in grade 1 of Junior High School (SMP) $(100 \%) ; 31$ female subjects $(73.8 \%)$ and 11 male subjects $(26.2 \%) ; 1$ subject aged 14 years old $(2.4 \%)$, 23 subjects aged 13 years old $(66.7 \%)$, and 13 subjects aged 12 years old (31\%); Islam (100\%); parents' education level at Elementary School (SD) level as many as 5 people (11.9), at Junior High School (SMP) level as many as 1 person $(2.4 \%)$, at Senior High School (SMA) level as many as 26 people $(61.9 \%)$, and at university level as many as 10 people $(23.8 \%)$.

Based on the calculation of normality and homogeneity test, it is found that the data in this study are normal and homogeneous. This can be seen from the significance value of SRL and PGI which is greater than $0.05(\mathrm{p}=0.200$; and 0.200). Meanwhile, the significance value of the homogeneity test calculation is 0.149 ( $p>0.05$ ).

The results of regression test statistical calculation show the magnitude of influence of PGI on SRL with a coefficient of 36,120 ( $p<0.001$ ). The better a student's PGI, the better his SRL is. This calculation also results in obtained equation of regression line $\mathrm{Y}=0.814+0.711 \mathrm{X}$. Each increase in the PGI score by 1 point will increase the SRL score by 1,525 . The results of this study are in line with the research of [29] that PGI has a positive relationship with SRL in individuals with low intelligence potential.

The results of statistical calculations show a significance of more than 0.05 for both PGI (0.854) and SRL (0.768) scores, in other words parents' educational background does not affect bullying victims' PGI and SRL. The mean of bullying victims' PGI about 3.2 - 3.4 and mean of SRL 3.0 3.2.

The effect of PGI on SRL on the results of this study can be explained by the SRL model. In Zimmerman's SRL model, SRL is an interaction between environment, behaviour, and the person himself [30] [31]. The person here is defined as self, such as abilities, talents, interests, goals, personality, and roles that are inherent in an individual [32]. According to Berkhout, Helmich, Teunissen, Berg, Vleunten \& Jaarsma [33], personal attributes affect SRL. These attributes include motivational beliefs, self-efficacy, attitudes about the importance of learning, belief in the results obtained, planning, monitoring, metacognition, ability to focus attention, understanding learning strategies, persistence, time management, environmental structure, ability to control emotions, seeking help, and self-control [33]. Self-efficacy and persistence are parts of PGI [16] Important parts of PGI include the cognitive components of self-efficacy, such as belief, attitude, and values, as well as behavioural components that focus on self-development and self-improvement [16] [34] [35]. because PGI is an intensive process in which an individual is aware of the need to change, and have a desire to be involved in the process [16].

\subsection{Discussion}

According to Zimmerman [36] in SRL an individual personally takes the initiative and tries directly to gain knowledge and skills without only depending on teachers, parents or other related parties. In other words, individuals with good SRL have an active personal character [37] and are independent. From Zimmerman's statement it is clear that SRL is related to individual desire and effort to be better (PGI), so parents' educational background does not contribute to one's SRL, including bullying victims' SRL. Nevertheless, the different level of parents' education will lead to different parenting styles [38]. These differences create different beliefs and living values, but if they are not taught to children in the right way, these differences will not affect children's PGI and SRL. Furthermore, family characteristics are also corelated to bullying that occurs in children [39]. These characteristics include father-mother involvement, family warmth and family structure, parental income, family cohesiveness, family quarrels [39] and residence [40]. Parents' educational background and family characteristics will contribute in reducing the effect bullying on children if those factors are used as sources of knowledge to teach children about bullying behavior. According to Hornby [41] parents can teach skills to face bullying to children based on the knowledge gained from their educational 
experience. This is why, if parents' knowledge to face bullying is not taught to their children, parents' educational background will not affect children's PGI and SRL when these children suffer from bullying. Parents involvement to telling and sharing about bullying can reduce bullying that happen to child [42] [43]. Parents who practices their education values and combine it with parenting style can reduce children involvement in bullying [42] [44]. This PGI is a protective factor in a person to reduce and prevent the impact of negative stress, and allows a person to return to their original state after experiencing stress [45] [46].

In addition, in the context of PGI, especially in academic environment, a individual needs a strategy to have better personality, namely SRL. Individu who have good PGI, know when and what of his to change, have plans and adaptive with his plans, use resources for change, and do their change intensive [47]. Its similar with the stage of SRL. Each stage of SRL, namely forethought and planning, performance and self-reflection, requires selfsupport [31], namely individual efforts to be better (PGI). Forethought and planning stages [48] require the ability of PGI to make task analysis, goal setting and planning learning strategies, and beliefs to selfmotivate. If an individual does not show active and continuous efforts in this phase, he will not be optimal in doing SRL in the second stage, namely performance. He will act without direction and will be confused in achieving goals so that he will be easily distracted in the learning process.

Personal growth initiation is also required at the second stage. The second stage is where an individual exercises self-control through selfinstruction, imagery, and focus on tasks and selfobservations on their performance [48]. This is because in PGI there is the so-called action stage in which an individual does not only think about changing for the better but also acting to be better. In academics context, if an individual has a good PGI, he will continue to try and not easily give up by disturbances when carrying out the second SRL stage.

In the third stage, namely self-reflection, SRL cannot be separated from PGI. According to Zimmerman [48] and Panadero [30], self-reflection in SRL is doing self-assessment through selfevaluation and its related attributes, and self-reaction in relation with self-satisfaction with the results achieved at performance stage. It is also related with changing planning strategies (adapting) or maintaining the strategy at the first stage of SRL and performance. In this third stage, if an individual has a strong effort to change himself for the better, namely good PGI, the he will have the courage to conduct self-evaluation of performance and dare to accept feelings as a result of his performance in the second stage. He will also be active in adapting to performance in the second stage and plan strategies if he fails in the first stage of SRL.

SRL is an active and ongoing process as long as individuals still have goals to achieve in learning. This active SRL process can be seen in the SRL cycle, where the forethought, performance and selfreflection stages are a continuous process [49] that demands continuous individual effort.

\subsection{Conclusion}

The conclusion of this study shows the effect of Personal Growth Initiative (PGI) on Self-Regulated Learning (SRL) of bullying victims. It also shows that parents' educational background does not contribute to bullying victims' PGI and SRL. The implication is parents have to teach their children to face bullying by care and communication. Other implication is teamwork from teacher, counsellor and psychologist to improve parents-children communication skill. In further research, it is desireable to expand the scope of research to level of education, cultural background, and socioeconomic status of the subjects, so that research on PGI and SRL of bullying victims is more in-depth. If necessary, qualitative data can be employed to deepen the research results.

\section{AUTHORS' CONTRIBUTIONS}

The author confirms responsibility for the following: study conception and design, data collection, analysis and interpretation of results, and manuscript preparation.

\section{ACKNOWLEDGMENTS}

This research was supported by Faculty of Psychology, Universitas Muhammadiyah Malang, Malang, Indonesia.

\section{REFERENCES}

[1] S. Graham. Victims of Bullying in Schools. Theory Pract. 2016, 55(2), 136-44.

[2] G. Suter. Book Reviews: Book Reviews. Integr Environ Assess Manag. 2015;11(3):520-2.

[3] P. Saraswati, S. Amalia. Perbedaan achivement goal dan pesonal growth inisiative pada pelaku dan korban bullying. Bunga Rampai Revitalisasi Peran Psikologi dalam Keluarga, Organisasi, dan Komunitas: Tantangan dalam Menyambut Society 5.0, Fakultas Psikologi 
Undip, 246-59.

[4] J.A. Dake, J.H. Price, S.K. Telljohann. The nature and extent of bullying at school. J Sch Health. 2003;73(5):173-80.

[5] W. Nasuha. 6 Kasus Kekerasan dan Bullying di Sekolah Awal 2019, Nomor 2 Berakhir Tragis [Internet]. okezone. 2019. Available from: https://nasional.okezone.com/read/2019/02/12 /337/2016872/6-kasus-kekerasan-dan-

bullying-di-sekolah-awal-2019-nomor-2berakhir-tragis

[6] Syukur, Bermula dari Perundungan, Pelajar di Pekanbaru Kritis Dianiaya Teman Sekelas [Internet]. liputan6.com. 2019. Available from: https://www.liputan6.com/regional/read/4106 072/bermula-dari-perundungan-pelajar-dipekanbaru-kritis-dianiaya-teman-sekelas.

[7] D. Prastiwi. 5 hal terkait bunuh diri pelajar di jakarta timur [Internet]. liputan6.com. 2019. Available from: https://www.liputan6.com/news/read/4161425 15-hal-terkait-bunuh-diri-pelajar-di-jakartatimur.

[8] J. Juvonen, S. Graham. Bullying in schools: The power of bullies and the plight of victims. Annu Rev Psychol. 2014;65:159-85.

[9] S.M. Swearer, S. Hymel. Understanding the psychology of bullying: Moving toward a social-ecological diathesis-stress model. Am Psychol. 2015;70(4):344-53.

[10] H.K. Al-Raqqad, E.S. Al-Bourini, F.M. Al Talahin, R.M.E. Aranki. The Impact of School Bullying On Students' Academic Achievement from Teachers Point of View. Int Educ Stud. 2017;10(6):44.

[11] C.B.R. Evans, P.R. Smokowski. Theoretical Explanations for Bullying in School: How Ecological Processes Propagate Perpetration and Victimization. Child Adolesc Soc Work J. 2016;33(4):365-75.

[12] J. Gruber, S. Fineran. Sexual Harassment, Bullying, and School Outcomes for High School Girls and Boys. Violence Against Women. 2016;22(1):112-33.

[13] D.H. Schunk, B.J. Zimmerman. Influencing children's self-Efficacy and self-regulation of reading and writing through modeling. Read Writ Q. 2007;23(1):7-25.

[14] M. Boekaerts. Self-regulated learning: Where we are today. Int J Educ Res. 1999;31(6):44557.

[15] A. Wigfield, S.L. Klauda, J. Cambria. Influences on the Development of Academic Self-Regulatory Processes. Handb SelfRegulation Learn Perform. 2015;

[16] C. Robitschek. Personal growth initiative: The construct and its measure. Meas Eval Couns
Dev. 1998;30(4):183-98.

[17] C. Robitschek, S.W. Cook. The influence of personal growth initiative and coping styles on career exploration and vocational identity. J Vocat Behav. 1999;54(1):127-41.

[18] D. Borowa, C. Robitschek, K.A. Harmon, Y. Shigemoto. Posttraumatic stress and growth in student service members and veterans: The role of personal growth initiative. J Am Coll Heal. 2016;64(7):527-34.

[19] J. Broadbent, W.L. Poon. Self-regulated learning strategies \& academic achievement in online higher education learning environments: A systematic review. Internet High Educ [Internet]. 2015;27:1-13. Available from: http://dx.doi.org/10.1016/j.iheduc.2015.04.00 7

[20] C.A. Wolters, M. Hussain. Investigating grit and its relations with college students' selfregulated learning and academic achievement. Metacognition Learn. 2015;10(3):293-311.

[21] J. Broadbent. Comparing online and blended learner's self-regulated learning strategies and academic performance. Internet High Educ [Internet]. 2017;33:24-32. Available from: http://dx.doi.org/10.1016/j.iheduc.2017.01.00 4

[22] M. Balkis, E. Duru. Procrastination , selfregulation failure, academic life satisfaction , and affective well-being: underregulation or misregulation form. 2015;(2009).

[23] E. DURU, S. DURU, M. BALKIS. Analysis of Relationships among Burnout, Academic Achievement, and Self-regulation. Educ Sci Theory Pract. 2014;14(4):1274-84.

[24] A. Kavanagh, N. Priest, E. Emerson, A. Milner, T. King. Gender, parental education, and experiences of bullying victimization by Australian adolescents with and without a disability. Child Care Health Dev. 2018;44(2):332-41.

[25] P. Pallavi. The role of educational background on the employee' $\mathrm{s}$ exposure to bullying. 2019;(April).

[26] K.E.N. Rigby. V. Henry. A Year Shakespear. 2020;73-5.

[27] D. Pasangan, Remaja P. Personal Growth Inisiatif ( Inisiatif Pertumbuhan Individu ) Personal Growth Inisiatif ( Inisiatif Pertumbuhan Individu ) Sebagai Prediktor Kemampuan Individu. 2020;(January):20-1.

[28] P. Saraswati. Kemampuan self regulated learning ditinjau dari achievement goal dan kepribadian pada remaja di Kota Malang. Indig J Ilm Psikol. 2019;4(2):69-78.

[29] T. Winarsunu, P. Saraswati. Psychological change on inclusive educators through 
emotional regulation. J Community Serv Empower. 2020;1(2):108-13.

[30] E. Panadero. A review of self-regulated learning: Six models and four directions for research. Front Psychol. 2017;8(APR):1-28.

[31] B.J. Zimmerman, A. Kitsantas. The Hidden Dimension of Personal Competence: SelfRegulated Learning and Practice. Handb competence Motiv [Internet]. 2005;(April):509-26. Available from: http://search.ebscohost.com/login.aspx?direct $=$ true $\& \mathrm{db}=$ psyh $\& \mathrm{AN}=2005-08058$ $027 \&$ lang $=$ it\&site $=$ ehost-live

[32] C. Stangor. Principles of Social Psychology 1st International Edition [Internet]. BCcampus; 2014. Available from: https://opentextbc.ca/socialpsychology/

[33] J.J. Berkhout, E. Helmich, P.W. Teunissen, van den Berg JW, van der Vleuten CPM, Jaarsma ADC. Exploring the factors influencing clinical students' self-regulated learning. Med Educ. 2015;49(6):589-600.

[34] Y. Shigemoto, M.W. Ashton, C. Robitschek. Predictors of Growth in the Aftermath of Traumatic Events: The Role of Personal Growth Initiative. J Loss Trauma [Internet]. 2016;21(5):399-409. Available from: http://dx.doi.org/10.1080/15325024.2015.111 0446

[35] I.K. Weigold, A. Weigold, S. Ling, M. Jang. College as a Growth Opportunity: Assessing Personal Growth Initiative and Selfdetermination Theory. J Happiness Stud [Internet]. 2020;(0123456789). Available from: https://doi.org/10.1007/s10902-02000312-x

[36] B.J. Zimmerman. A Social Cognitive View of Self-Regulated Academic Learning. J Educ Psychol. 1989;81(3):329-39.

[37] A.L. Dent, A.C. Koenka. The Relation Between Self-Regulated Learning and Academic Achievement Across Childhood and Adolescence: A Meta-Analysis. Educ Psychol Rev. 2016;28(3):425-74.

[38] K.E. Herne. 'It's the parents': re-presenting parents in school bullying research. Crit Stud Educ. 2016;57(2):254-70.

[39] M.K. Holt, G.K. Kantor, D. Finkelhor. Parent/child concordance about bullying involvement and family characteristics related to bullying and peer victimization. J Sch Violence. 2009;8(1):42-63.

[40] Y. Bjereld, K. Daneback, M. Petzold. Differences in prevalence of bullying victimization between native and immigrant children in the Nordic countries: A parentreported serial cross-sectional study. Child
Care Health Dev. 2015;41(4):593-9.

[41] G. Hornby. Bullying: An ecological approach to intervention in schools. Prev Sch Fail. 2016;60(3):222-30.

[42] N. Axford, D.P. Farrington, S. Clarkson, G.J. Bjornstad, Z. Wrigley, J. Hutchings. Involving parents in school-based programmes to prevent and reduce bullying: What effect does it have? J Child Serv. 2015;10(3):242-51.

[43] E. Larrañaga, S. Yubero, R. Navarro. Parents' responses to coping with bullying: Variations by adolescents' self-reported victimization and parents' awareness of bullying involvement. Soc Sci. 2018;7(8).

[44] O. Gómez-Ortiz, C. Apolinario, E.M. Romera, R. Ortega-Ruiz. The role of family in bullying and cyberbullying involvement: Examining a new typology of parental education management based on adolescents' view of their parents. Soc Sci. 2019;8(1).

[45] N. Ayub, S. Iqbal. The relationship of personal growth initiative, psychological well-being, and pyschological distress among adolescents. J Teach Educ. 2012;1(6):101-7.

[46] I.K. Weigold, A. Weigold, E.J. Russell, G.L. Wolfe, J.L. Prowell, C.A. Martin-Wagar. Personal Growth Initiative and Mental Health: A Meta-Analysis. J Couns Dev. 2020;98(4):376-90.

[47] C. Robitschek, M.A. Thoen. Personal growth and development. 2015.

[48] B.J. Zimmerman. Chapter 2: Attening selfregulation A social cognitive perspective. Handb Self-Regulation. 2000;13-39.

[49] Zimmerman \& Moylan. Self-regulation: Where metacognition and motivation intersect. In: The educational psychology series Handbook of metacognition in education [Internet]. Routledge/Taylor \& Francis Group; 2009. p. 299-315. Available from: https://psycnet.apa.org/record/2010-06038016 